\title{
Combined effect of $17 \beta$-estradiol and resveratrol against apoptosis induced by interleukin-1 $\beta$ in rat nucleus pulposus cells via PI3K/Akt/caspase-3 pathway
}

Si-Dong Yang, Lei Ma, Da-Long Yang, Wen-Yuan Ding

Background: In previous studies, both $17 \beta$-estradiol (E2) and resveratrol (RES) were reported to protect intervertebral disc cells against aberrant apoptosis. Given that E2 has a better anti-apoptotic effect with more cancer risk and RES has an anti-apoptotic effect with less cancer risk, the combined use of E2 with RES is promising in developing clinical therapies to treat apoptosis-related diseases such as intervertebral disc degeneration in the future. Objective: The purpose of this study was to explore the combined effect of E2 with RES on rat nucleus pulposus cells and the underlying mechanisms. Methods: TUNEL assay and FACS analysis were used to determine apoptotic incidence of nucleus pulposus cells. MTS assay was used to determine cell viability, and cellular binding assay was used to determine cell-ECM (extracellular matrix) ability. Real-time quantitative RT-PCR was to determine mRNA level of target genes. And western blot was used to determine the protein level. Results: Both E2 and RES decreased apoptotic incidence when used singly; interestingly, they decreased apoptosis more efficiently when used combinedly.

Meanwhile, E2 and RES combined together against the decrease of cell viability and binding ability resulting from IL-1 $\beta$ cytotoxicity. As well, activated caspase- 3 was suppressed by the combined effect. Furthermore, IL-1 $\beta$ downregulated expression level of type II collagen and aggrecan (standing for anabolism), while upregulated MMP-3 and MMP-13 (standing for catabolism). However, the combined use of E2 with RES effectively abolished the above negative effects caused by IL-1 $\beta$, better than either single use. Finally, it turned out to be that E2 and RES combined together against apoptosis via the activation of PI3K/Akt/caspase-3 pathway. Conclusion: This study presented that IL-1 $\beta$ induced aberrant apoptosis, which was efficiently resisted by the combined use of E2 with RES via $\mathrm{PI} 3 \mathrm{~K} / \mathrm{Akt} / \mathrm{caspase-3}$ pathway. 
1 Combined effect of 17ß-estradiol and resveratrol against apoptosis induced by interleukin-

$21 \beta$ in rat nucleus pulposus cells via PI3K/Akt/caspase-3 pathway

3 Si-Dong Yang ${ }^{1 *}$, Lei Ma ${ }^{1 *}$, Da-Long Yang ${ }^{1 *}$, and Wen-Yuan Ding ${ }^{1,2}$

51 Department of Spinal Surgery, The Third Hospital of Hebei Medical University, 139Ziqiang

6 Road, Shijiazhuang, 050051, People's Republic of China.

72 Hebei Provincial Key Laboratory of Orthopaedic Biomechanics, 139Ziqiang Road, $8 \quad$ Shijiazhuang, 050051, People's Republic of China.

9 To whom correspondence should be addressed: Prof. Wen-Yuan Ding, M.D., Department of 10 Spinal Surgery, The Third Hospital of Hebei Medical University; Hebei Provincial Key 11 Laboratory of Orthopedic Biomechanics, 139Ziqiang Road, Shijiazhuang, 050051, People's 12 Republic of China. Telephone and Fax number: +86 311 87023626. E-mail address: 13 dingwyster@126.com

$14 *$ These authors contributed equally to this study.

\section{FOOTNOTES}

Abbreviations: IVD, intervertebral disc; IVDD, intervertebral disc degeneration; ECM, extracellular matrix; NP, nucleus pulposus; NPCs, nucleus pulposus cells; IL-1 $\beta$, interleukin-1 $\beta$; E2, 17ß-estradiol; ICI, ICI182780; TUNEL, Terminal-deoxynucleoitidyl Transferase Mediated Nick End Labeling; RT-qPCR, reverse transcription and real-time quantitative polymerase chain reaction; MMP, matrix metalloproteinase; FBS, fetal bovine serum; RES, resveratrol; ER, estrogen receptor; LY, LY294002; COL2 $\alpha 1$, type II collagen; SIRT, sirtuin; ROS, reactive oxygen species 
ABSTRACT

Background: In previous studies, both 17ß-estradiol (E2) and resveratrol (RES) were reported to protect intervertebral disc cells against aberrant apoptosis. Given that E2 has a better antiapoptotic effect with more cancer risk and RES has an anti-apoptotic effect with less cancer risk, the combined use of E2 with RES is promising in developing clinical therapies to treat apoptosisrelated diseases such as intervertebral disc degeneration in the future.

Objective: The purpose of this study was to explore the combined effect of E2 with RES on rat nucleus pulposus cells and the underlying mechanisms. resisted by the combined use of E2 with RES via PI3K/Akt/caspase-3 pathway. 


\section{INTRODUCTION}

Clinically, intervertebral disc (IVD) degeneration (IVDD) is commonly seen, which is often associated with lower back pain. It has been demonstrated in previous studies that aberrant apoptosis and accelerated ageing of nucleus pulposus cells (NPCs) are considered as the two major cellular processes which are closely related to IVDD (Le, Freemont\&Hoyland, 2007; Yang et al., 2015). It indicates that NPC apoptosis may be a potential target when we think about prevention and treatment of IVDD.

In our in-vitro studies, (E2) has been found to have a protective effect on rat IVD cells (Wang et al., 2014; Yang et al., 2014, 2015). In addition, E2 has been elucidated to protect against aberrant apoptosis on NPCs via the up-regulation of type II collagen (COL2 $\alpha 1$ ) and aggrecan, and down-regulation of MMP-3 and MMP-13 (Yang et al., 2015). However, estrogen use is often related to more cancer risk. Thus, it limits its further use in clinical aspect. Resveratrol (RES) is a natural polyphenol compound, also known as a phytoestrogen (Li et al., 2008; Zou et al., 2014). In recent years, some in-vivo (Wuertz et al., 2011; Kwon, 2013) and invitro studies (Li et al., 2008; Wuertz et al., 2011; Shen et al., 2013) have reported its protective effect on IVD. It was reported that RES significantly protected rabbit discs by decreasing loss of aggrecan and inhibiting MMP-13 level (Kwon, 2013). In addition, RES can effectively restrain inflammatory factor IL-6, IL-8 (Wuertz et al., 2011), suppress catabolism including MMP-1, MMP-3, MMP-13, and ADAMTS-4 (Li et al., 2008; Wuertz et al., 2011; Kwon, 2013), and enhance anabolism of proteoglycan ( $\mathrm{Li}$ et al., 2008).

Furthermore, E2 (Jover-Mengual et al., 2010; Huang et al., 2011; Ld et al., 2012; Garrido et al., 2013; Mo et al., 2013; Okoh et al., 2013; Qi et al., 2014) and RES (Venkatachalam et al., 2008; Jiang et al., 2009; Roy et al., 2009; Chan et al., 2013; Tsai et al., 2013; Lin et al., 2014; Sui et al., 2014; Chong et al., 2015; Liu et al., 2015) have been widely reported to have a close 
82

relationship with PI3K/Akt signal pathway. Also, it has been found that estrogen receptors (ERs, including ER- $\alpha$ and ER- $\beta$ ) are involved in the RES-mediated effects (Robb\&Stuart, 2011; Di et al., 2012; Nwachukwu et al., 2014).

Therefore, given that E2 has a better anti-apoptotic effect with more cancer risk and RES has an anti-apoptotic effect with less cancer risk, we have built the hypothesis that the combined use of E2 with RES may potentially play a more efficient role in retarding the progress of IVDDrelated diseases. The aim of the present study is to explore the combined effect of E2 with RES on cell apoptosis induced by IL-1 $\beta$ in rat NPCs. In the meanwhile, the role of PI3K/Akt pathway in signal transduction has been preliminarily studied.

\section{MATERIAL AND METHODS}

\section{Ethics statement}

Animal protocols were approved by the Institutional Animal Care and Use Committee of The Third Hospital of Hebei Medical University. The approval number is K2015-019-1.

\section{Reagents and antibodies}

The information about reagents and antibodies used in this study was collected in Table 1.

\section{Cell culture}

Cell culture was performed according to our previous report (Yang et al., 2015). Briefly, three male Sprague-Dawley rats ( 200g, 2 months) were sacrificed by anesthetic overdose with pentobarbital sodium. Lumbar spinal columns were removed en bloc under aseptic conditions, and lumbar IVDs were collected. The gel-like nucleus pulposus was separated from the annulus fibrosus under a dissecting microscope and was sequentially treated with $0.25 \%$ type II collagenase for 1 hour and $0.2 \%$ trypsin with EDTA $(1 \mathrm{mmol} / \mathrm{L})$ for 5 minutes. The solution containing partially digested tissue was then transferred to a $50 \mathrm{~mL}$ culture flask containing DMEM and $20 \% \mathrm{FBS}$ and cultured in a humidified atmosphere of $5 \% \mathrm{CO}_{2}$ at $37^{\circ} \mathrm{C}$. NPCs were adherent to the bottom of culture flask after 3 days. When confluent (after 1 week), NPCs were dissociated using $0.25 \%$ trypsin with EDTA $(1 \mathrm{mmol} / \mathrm{L})$ solution and further sub-cultured. The primary cultured cells were seeded in triplicates. First-passage (P1) cells maintained in 
monolayers were used for the following experiments ( $n=6$ per group). FBS is known to contain a variety of growth factors and other factors required for cells to survive in culture. It is therefore likely that it would be better to use IL-1 $\beta$ to induce cell apoptosis with serum deprivation. Moreover, phenol red, a $\mathrm{pH}$ indicator that has weak estrogenic properties, strongly improved cell proliferation and reduced cell apoptosis (Yang et al., 2014). Therefore, the presence of phenol red may to some degree disturb the accuracy of experimental data and as a result, reduce the reliability of the whole research. Therefore, all experiments in this study were conducted without phenol red.

\section{Fluorescence-activated cell sorting (FACS) analysis}

FACS analysis was performed according to our previous report (Yang et al., 2015). NPCs were plated into 6-well plates at a density of $2 \times 10^{5}$ cells per well and divided into ten groups. As a control, group A was treated with vehicle mixture (ethanol and DMSO, $<0.1 \%$; ethanol was the solvent of E2 and DMSO was the solvent of RES). Group B was treated with $75 \mathrm{ng} / \mathrm{ml} \mathrm{IL-1 \beta}$ (Yang et al., 2015). Group C was treated with $75 \mathrm{ng} / \mathrm{ml}$ IL-1 $\beta$ with the pretreatment of $1 \mu \mathrm{M}$ E2 for $30 \mathrm{~min}$ (Yang et al., 2015). Group D was treated with $75 \mathrm{ng} / \mathrm{ml} \mathrm{IL-1 \beta}$ with the pretreatment of $10 \mu \mathrm{M}$ RES for $30 \mathrm{~min}$. Group E was treated with $75 \mathrm{ng} / \mathrm{ml} \mathrm{IL-1} \beta$ with the pretreatment of $100 \mu \mathrm{M}$ RES for $30 \mathrm{~min}$. Group F was treated with $75 \mathrm{ng} / \mathrm{ml}$ IL-1 $\beta$ with the pretreatment of 200 $\mu \mathrm{M}$ RES for $30 \mathrm{~min}$. Group $\mathrm{G}$ was treated with $75 \mathrm{ng} / \mathrm{ml} \mathrm{IL}-1 \beta$ with the pretreatment of $1 \mu \mathrm{M} \mathrm{E} 2$ and $10 \mu \mathrm{M}$ RES for $30 \mathrm{~min}$. Group $\mathrm{H}$ was treated with $75 \mathrm{ng} / \mathrm{ml} \mathrm{IL-1 \beta}$ with the pretreatment of 1 $\mu \mathrm{M}$ E2 and $100 \mu \mathrm{M}$ RES for $30 \mathrm{~min}$. Group I was treated with $75 \mathrm{ng} / \mathrm{ml} \mathrm{IL-1 \beta}$ with the

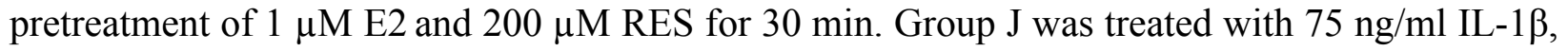
$1 \mu \mathrm{M}$ E2 and $200 \mu \mathrm{M}$ RES, with the pretreatment of $1 \mu \mathrm{M}$ ICI182780 for $30 \mathrm{~min}$. For all subsequent experiments, RES was used at a concentration of $200 \mu \mathrm{M}$, as this is the maximum concentration found to maintain disc cell viability and provide consistency from experiment to experiment ( $\mathrm{Li}$ et al., 2008). All groups were incubated for $24 \mathrm{~h}$ in the serum-free medium without phenol red. Apoptotic cells were detected using an Annexin V-FITC/PI kit (BD Pharmingen, San Jose, CA) according to the manufacturer's instructions. Annexin V and PI 
136 binding were assessed (within $1 \mathrm{~h}$ ) using a flow cytometer (BD Biosciences, San Jose, CA) with 137 CellQuest (BD Biosciences, San Jose, CA) software. Apoptotic cells, stained positive for annexin V-FITC, negative for PI, or double positive, were counted. In the experiments, no less than 3,500 cells per sample were analyzed by FACS. In fact, most were more than 5000 cells per sample that were analyzed by FACS. Data are represented as a percentage of the total cell count.

\section{Inverted fluorescence microscopy}

NPCs were divided into five groups. As a control, group A was treated with vehicle mixture (ethanol and DMSO, $<0.1 \%$; ethanol was the solvent of E2 and DMSO was the solvent of RES).

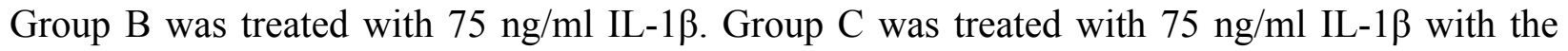
pretreatment of $1 \mu \mathrm{M}$ E2 for $30 \mathrm{~min}$. Group D was treated with $75 \mathrm{ng} / \mathrm{ml}$ IL-1 $\beta$ with the pretreatment of $200 \mu \mathrm{M}$ RES for $30 \mathrm{~min}$. Group E was treated with $75 \mathrm{ng} / \mathrm{ml} \mathrm{IL-1 \beta}$ with the pretreatment of $1 \mu \mathrm{M}$ E2 and $200 \mu \mathrm{M}$ RES for $30 \mathrm{~min}$. All groups were incubated for $24 \mathrm{~h}$ in the serum-free medium without phenol red. TUNEL assay was performed to detect apoptosis according to manufacturer's instructions. Apoptotic changes of NPCs were observed under an inverted fluorescence microscope (Olympus, Japan) and photographed by a digital camera (Nikon, Japan). About 200 cells were counted per sample in the analysis of apoptotic changes of NPCs by the Tunel assay.

\section{MTS assay}

Cell viability was determined by MTS assay using CellTiter 96® AQueous MTS Reagent Solution (Promega, Madison, WI) according to manufacturer's instruction. NPCs were treated in five groups as above and then seeded into 96-well plates. The optical density was measured at $492 \mathrm{~nm}$ with a microplate reader (Shimadzu, Kyoto, Japan) and cell viability was normalized as a percentage of control.

\section{Cellular binding assay}

Rat NPCs were treated in five groups as described above and then assayed for their ability to bind COL2 $\alpha 1$ according to the reported method (Yang et al., 2014). Briefly, a 24-well plates were coated over night at $4{ }^{\circ} \mathrm{C}$ with COL2 $\alpha 1$ (Sigma, $20 \mu \mathrm{g} / \mathrm{ml}$ ). Non-specific binding sites were 
163 blocked by incubating the coated plates with $10 \mathrm{mg} / \mathrm{ml}$ albumin for $60 \mathrm{~min}$ followed by two washes with ice-cold PBS. A total of 30,000 cells were placed in each well and allowed to adhere at $37{ }^{\circ} \mathrm{C}$ for $60 \mathrm{~min}$. After adhesion, cells were stained with $0.5 \%$ toluidine blue, fixed with 4\% paraformaldehyde, and solubilized in 1\% SDS. Extracted dye was quantified by measuring absorbance value at $590 \mathrm{~nm}$ in a plate reader (Dynatech MR5000, Germany).

\section{Active caspase-3 activity assay}

Active caspase-3 activity was performed according to our previous report (Yang et al., 2015). NPCs $\left(2 \times 10^{5}\right)$ were cultured in 6-well plates in five groups as described above. Caspase-3 activity was determined using a caspase-3 activity kit (Beyotime, Shanghai, China), which is based on the ability of caspase-3 to catalyze the formation of a yellow formazan product, $\mathrm{p}$ nitroaniline, from acetyl-Asp-Glu-Val-Asp p-nitroanilide. As recommended by the manufacturer's protocol, treated cells were lysed with lysis buffer $\left(100 \mu \mathrm{L}\right.$ per $2 \times 10^{6}$ cells $)$ for 15 min on ice followed by washing with cold PBS. Solutions containing $10 \mu \mathrm{L}$ cell lysate, $80 \mu \mathrm{L}$ reaction buffer and $10 \mu \mathrm{L} 2 \mathrm{mM}$ caspase-3 substrate were then incubated in 96-well microtiter plates at $37^{\circ} \mathrm{C}$ for $3 \mathrm{~h}$. Caspase- 3 activity was quantified with a microplate spectrophotometer (Biotek, Vermont, US) at an absorbance of $405 \mathrm{~nm}$. Caspase-3 activity is expressed as the fold change in enzyme activity over control.

\section{RT-qPCR}

PCR was performed according to our previous report (Yang et al., 2015). The changes of mRNA were detected by RT-qPCR (reverse transcription and real-time quantitative polymerase chain reaction). A total of $10 \mu \mathrm{g}$ RNA was isolated with Trizol (Solarbio, Beijing, China) according to the manufacturer's instructions. Total RNA was measured fluorometrically using a CyQuant-Cell Proliferation Assay Kit (Molecular Probes, Eugene, OR). cDNA synthesis was performed using a ThermoScript RT-qPCR System (Invitrogen, Shanghai, China). For quantification of genes of interest we utilized a DyNAmo SYBR Green 2-step RT-qPCR Kit (Promega, Madison, WI) in a total volume of $20 \mu \mathrm{L}$, with real-time PCR performed using an Mx300P cycler. Amplicons of target genes were amplified with the primers designed with 
Primer Premier Version 5.0 software and their efficiency was confirmed by sequencing their conventional PCR products (Table 2). PCR amplification was performed using the following protocol: $95^{\circ} \mathrm{C}$ for $2 \mathrm{~min}$, then 40 cycles of $95^{\circ} \mathrm{C}$ for $15 \mathrm{sec}$, and finally $60^{\circ} \mathrm{C}$ for $1 \mathrm{~min}$. Standard curves were generated for each assay to produce a linear plot of threshold cycle $(\mathrm{Ct})$ against $\log$ (dilution). Target gene expression was quantified according to the concentration of the standard curve. Data are presented as relative $\mathrm{Ct}$ values $(n=6)$. Relative gene expression data was calculated according to the $2^{-\Delta \Delta \mathrm{Ct}}$ method. Target gene expression was normalized to reference gene (GAPDH).

\section{Western blot}

Western blot was performed according to our previous report (Yang et al., 2015). Protein levels of Akt, p-Akt (Ser473) and active caspase-3 was determined by western blot, with GAPDH as internal reference protein. Rat NPCs were washed with ice-cold PBS and harvested in $100 \mu \mathrm{L}$ of cell Lysis buffer containing 1\% protease inhibitor (Solarbio, Beijing, China). Lysates were centrifuged at $4^{\circ} \mathrm{C}$ for $5 \mathrm{~min}$ at $14,000 \mathrm{rpm}$ and resolved on $12 \%$ SDSpolyacrylamide gels (SDS-PAGE). Proteins were transferred by electroblotting to a PVDF membrane (Merk Millipore, Billerica, MA). The membranes were blocked with 5\% non-fat dry milk in TBS (50 mmol/L Tris, $\mathrm{pH} 7.6,150 \mathrm{mmol} / \mathrm{L} \mathrm{NaCl}, 0.1 \%)$ and incubated overnight at $4^{\circ} \mathrm{C}$ in 5\% non-fat dry milk in PBST with corresponding first antibodies (dilution 1:500). Washing in PBST 3 times for $30 \mathrm{~min}$, the membrane was incubated with a secondary anti-IgG-HRP antibody (dilution 1:5000) at room temperature for $2 \mathrm{~h}$. Immunolabeling was detected using enhanced chemiluminescence (ECL) reagent (Solarbio, Beijing, China).

\section{Statistical analysis}

Statistical analyses were performed using SPSS for Windows, version 18.0 (SPSS Inc., USA). All data are presented as the mean \pm SD (standard deviation) of independent experiments performed ( $\mathrm{n}=6$ for each group). If data satisfied criteria for normality and homogeneity of variance, statistical analysis among multiple groups was performed using one-way analysis of variance (ANOVA), accompanied by pairwise comparison using the SNK-q test. If not, 
217 statistical analysis was performed using non-parametric rank test. $p<0.05$ was regarded as 218 statistically significant.

\section{RESULTS}

220 FACS analysis

As shown in Fig $1 \mathrm{~A}$ and Fig 1B, IL-1 $\beta$ resulted in a marked increase (up to 14\%) of

222

223

224

225

226

227

228

229

230

231

232

233

234

235

236

237

238

239

240

241

242

243

apoptotic incidence. However, the apoptotic incidence induced by IL-1 $\beta$ could be effectively decreased by the single use of $1 \mu \mathrm{M}$ E2 or $200 \mu \mathrm{M}$ RES, as well as the combined use of $1 \mu \mathrm{M}$ E2 and $200 \mu \mathrm{M}$ RES.

\section{Inverted fluorescence microscopy}

As shown in Fig $2 \mathrm{~A}$ and Fig 2B, TUNEL assay showed that IL-1 $\beta$ induced marked apoptosis (14\%) compared to control (7\%), which was effectively reversed by the combined use of $1 \mu \mathrm{M}$ E2 and $200 \mu \mathrm{M}$ RES (4.5\%).

\section{MTS assay, cellular binding and active caspase-3 activity}

As shown in Fig 3, Fig 4, and Fig 5, IL-1 $\beta$ resulted in a decrease of nearly $30 \%$ both in cell viability $(p<0.05)$ and cell binding ability $(p<0.05)$, as well as an increase of 4 fold in activated caspase-3 activity $(p<0.05)$. However, the cytotoxic effects of IL-1 $\beta$ were partly abolished by the addition of E2 or RES, but all were reversed by the combined use of $1 \mu \mathrm{M}$ E2 and $200 \mu \mathrm{M}$ RES $(p<0.05)$.

\section{RT-qPCR}

As shown in Fig 6, IL-1 $\beta$ significantly reduced 30\% COL $2 \alpha 1$ and 40\% aggrecan, while increased 4 fold of MMP-3 and 5 fold of MMP-13, as compared to control (all $p<0.05$ ). Of note, the combined use of $1 \mu \mathrm{M}$ E2 and $200 \mu \mathrm{M}$ RES increased 25\% COL2 $\alpha 1$ and 30\% aggrecan, while decreased 3.5-fold MMP-3 and 4.5-fold MMP-13, as compared to IL-1 $\beta$ group (all $p<0.05$ ).

\section{Western blot}

As shown in Fig 7, relative value of $p$-Akt/GAPDH was up-regulated to 0.75 by the combined use of E2 and RES, while it was down-regulated to 0.15 by the addition of ER 
244 antagonist (ICI), or LY294002 (a PI3K/Akt inhibitor). Besides, cleaved caspase-3 was 245 upregulated by IL-1 $\beta$, but then downregulated by the addition of E2 and RES $(p<0.05)$.

\section{DISCUSSION}

In the present study, data show that the gene expression levels of MMP-3 and MMP-13 are both increased while the levels of type II collagen and aggrecan are decreased, due to cytotoxic effect of IL-1 $\beta$. It is notable that the combined use of E2 and RVS has markedly decreased the cytotoxic effect of IL-1 $\beta$ on NPCs, which was presented as the down-regulation of catabolism (the decreased levels of MMP-3 and MMP-13), and the upregulation of anabolism (the increased levels of COL2 $\alpha 1$ and aggrecan). Although the single use of E2 or RES can inhibit the catabolism due to cytotoxic effect of IL-1 $\beta$, obviously, the combined regulation of E2 with RVS is more effective.

As compared to RES, E2 exerts a better effect to reverse the adverse regulation caused by

IL-1 $\beta$, which is indicated by FACS analysis that more apoptotic incidence is decreased. As well, cellular viability and cell binding is restored more in E2 group than those in RES group. Meanwhile, more catabolism due to cytotoxic effect of IL-1 $\beta$ is prohibited by E2 than RES, with more anabolism increased by E2. However, it is no doubt in this study that the combined use of E2 with RES has an advantage over the single use of E2 or RES. And, E2 combined with RES protects rat NPCs against apoptosis, characterized by enhanced biosynthesis of COL $2 \alpha 1$ and aggrecan, as well as increased cell viability and binding ability.

It has long been recognized that there is a continuous increase in cell death during human IVDD. Additionally, nutrient supply to the IVD deteriorates during disc degeneration in humans (Yang et al., 2014). However, it should be noted in the present study that the cytokine IL-1 $\beta$ is sufficient to induce apoptosis of NPCs based on serum deprivation. Indeed, previous studies (Zhao et al., 2007; Yang et al., 2014) demonstrate that although suppression of apoptosis increases IVD cell survival, IVD cells inevitably die without an adequate supply of nutrients. Thus, improving the IVD nutrient supply may be beneficial for suppression of IVD cell apoptosis. 
It is well-known that estrogen has been closely related to cancer risk, especially breast cancer. Different from E2, as a polyphenolic compound, RVS has anti-inflammatory, antioxidant, neuroprotective properties and acts as a chemopreventive agent (Jiang et al., 2009). RVS causes cell cycle arrest and induces apoptotic cell death in various types of cancer cells (Jiang et al., 2009; Tsai et al., 2013). Contrary to the situation in cancer cells, RVS has a protective effect on intervertebral disc cells from apoptosis ( $\mathrm{Li}$ et al., 2008), as the same in the current study. However, the anti-apoptotic effect of RVS is a little poorer than E2. Given that E2 has a better anti-apoptotic effect with more cancer risk and RES has an anti-apoptotic effect with less cancer risk, the combined use of E2 with RES is promising in developing clinical therapies to treat apoptosis-related diseases such as IVDD in the future.

RVS has beneficial effects on aging, inflammation and metabolism, which are thought to result from activation of the lysine deacetylase, sirtuin 1 (SIRT1), the cAMP pathway, or AMPactivated protein kinase (Nwachukwu et al., 2014). To our knowledge, both E2 (Jover-Mengual et al., 2010; Huang et al., 2011; Ld et al., 2012; Garrido et al., 2013; Mo et al., 2013; Okoh et al., 2013; Qi et al., 2014) and RES (Venkatachalam et al., 2008; Jiang et al., 2009; Roy et al., 2009; Chan et al., 2013; Tsai et al., 2013; Lin et al., 2014; Sui et al., 2014; Chong et al., 2015; Liu et al., 2015) have been widely reported to have a close relationship with PI3K/Akt signal pathway. Also, it has been found that ERs, including ER- $\alpha$ and ER- $\beta$, are involved in the RES-mediated effects (Robb\&Stuart, 2011; Di et al., 2012; Nwachukwu et al., 2014). In the present study, a preliminary exploration has been performed to detect the involvement of PI3K/Akt pathway in signal transduction arising in the anti-apoptotic process of E2 combined with RES. It was noted that E2 combined with RES activated and upregulated the PI3K/Akt signal pathway, which could be inhibited by LY, as well as ICI. Hence, these results above further confirmed that E2 and RES exert their effects based on the same receptors. However, the relationship of E2 and RES may change in different situations, especially influenced by the dose of RES, as RES may act as an agonist (Macpherson\&Matthews, 2010) or an antagonist to compete with E2 for binding to ER- $\alpha$ (Chakraborty, Levenson\&Biswas, 2013). That is to say, RES has partial antagonist and partial 
298

299

300

301

302

agonist actions on ER- $\alpha$ (Chakraborty, Levenson\&Biswas, 2013). Up to now, the ER subtypes that RES interacts with are controversial, with regard to ER- $\alpha$ (Macpherson\&Matthews, 2010; Di et al., 2012; Kang et al., 2013; Nwachukwu et al., 2014) or ER- $\beta$ (Jackson, Greiwe\&Schwen, 2011; Robb\&Stuart, 2011; Di et al., 2012; Chen\&Chien, 2014). As for the present study, RES acts as an agonist to enhance the cytoprotective effect of E2.

To our knowledge, the potential benefit of RES mainly results from its antioxidant effect (Gueguen et al., 2015) and the interaction with SIRT (Kaeberlein et al., 2005). Oxidative stress arises from a shift in balance that favors the generation of oxygen-derived reactive oxygen species (ROS) over certain antioxidant defense mechanisms (Meng et al., 2015). ROS can induce peroxidation of lipid, leading to a loss of membrane integrity, reduction of mitochondrial membrane potential, and increased permeability to $\mathrm{Ca} 2+$ in the plasma membrane (Wassmann, Wassmann\&Nickenig, 2004). Mitochondria are key targets of RES. Some previous studies have found, RES modulates mitochondrial ROS production, mitochondrial biogenesis (Kitada et al., 2011) via its interaction with SIRT1 (Bastin, Lopes-Costa\&Djouadi, 2011) and energy metabolism via either transcriptional (Zhou et al., 2014) or enzymatic activation of SIRT3 (Chen et al., 2013). With regard to the current work, it is just a preliminary study on the role of $\mathrm{PI} 3 \mathrm{~K} /$ Akt pathway in signal transduction. Therefore, there are no experiments performed to explore the mitochondrial pathway or oxidative stress. Surely, this is the limitation of our work, which is designed to be explored in a further study.

Up to now, no study has reported any differences between men and women in response to the suggested treatment including E2 in combination with RES, to treat IVDD-related diseases. As we know, women are more sensitive to estrogen deficiency. Thus, this treatment may be more effective to women than men. Surely, when seeking for the potential of E2 in combination with RES, we have to face the possible side effects. One of them is always associated with breast cancer caused by much estrogen use. However, RES has been shown to be a potential protective agent against cancer, inflammatory lesions, diabetes mellitus, and cardiovascular abnormalities. (Baur\&Sinclair, 2006; Zou et al., 2014) Hence, the side effect of E2 in combination with RES is 
325

326

327

328

329

330

331

332

333

334

335

336

337

338

339

340

341

342

343

344

345

346

347

348

349

350

351

352

353

354

355

356

357

358 unclear regarding their oncogenicity, due to their opposite effects. Further studies on their side effects are needed.

The obtained results from this study were in vitro results. In order to draw any conclusions about the in vivo situation, animal experiments needs to be performed since results from in vitro models cannot always be compared and/or applied to the in vivo situation. Thus, the results in this study suggest a role in vivo of the investigated combined anti-apoptotic effects via PI3K/Akt/caspase-3 signaling pathway of E2 and RES in IVDD. This research provides a novel insight into the anti-apoptotic effect of E2 combined with RES, potentially leading to a better understanding of clinical therapies based on apoptosis, especially to retard the progress of IVDD.

\section{References}

Bastin J, Lopes-Costa A, Djouadi F. 2011. Exposure to resveratrol triggers pharmacological correction of fatty acid utilization in human fatty acid oxidation-deficient fibroblasts. Hum Mol Genet 20:2048-2057. DOI:10.1093/hmg/ddr089

Baur JA, Sinclair DA. 2006. Therapeutic potential of resveratrol: the in vivo evidence. Nat Rev Drug Discov 5:493-506. DOI:10.1038/nrd2060

Chakraborty S, Levenson AS, Biswas PK. 2013. Structural insights into Resveratrol's antagonist and partial agonist actions on estrogen receptor alpha. BMC Struct Biol 13:27. DOI:10.1186/1472-6807-13-27

Chan CM, Chang HH, Wang VC, Huang CL, Hung CF. 2013. Inhibitory effects of resveratrol on PDGF-BB-induced retinal pigment epithelial cell migration via PDGFRbeta, PI3K/Akt and MAPK pathways. PLoS One 8:e56819. DOI:10.1371/journal.pone.0056819

Chen C, Jiang X, Zhao W, Zhang Z. 2013. Dual role of resveratrol in modulation of genotoxicity induced by sodium arsenite via oxidative stress and apoptosis. Food Chem Toxicol 59:8-17. DOI:10.1016/j.fct.2013.05.030

Chen FP, Chien MH. 2014. Phytoestrogens induce apoptosis through a mitochondria/caspase pathway in human breast cancer cells. Climacteric 17:385-392. DOI:10.3109/13697137.2013.869671

Chong E, Chang SL, Hsiao YW, Singhal R, Liu SH, Leha T, Lin WY, Hsu CP, Chen YC, Chen YJ, Wu TJ, Higa S, Chen SA. 2015. Resveratrol, a red wine antioxidant, reduces atrial fibrillation susceptibility in the failing heart by PI3K/AKT/eNOS signaling pathway activation. Heart Rhythm 12:1046-1056. DOI:10.1016/j.hrthm.2015.01.044

Di LV, Makela J, Korhonen L, Olivieri M, Tselykh T, Malkia A, Do TH, Belluardo N, Lindholm D, Mudo G. 2012. Involvement of estrogen receptors in the resveratrol-mediated increase in dopamine transporter in human dopaminergic neurons and in striatum of female mice. Neuropharmacology 62:1011-1018. DOI:10.1016/j.neuropharm.2011.10.010

Garrido P, Moran J, Alonso A, Gonzalez S, Gonzalez C. 2013. 17beta-estradiol activates glucose uptake via GLUT4 translocation and PI3K/Akt signaling pathway in MCF-7 cells. Endocrinology 154:1979-1989. DOI:10.1210/en.20121558 
Gueguen N, Desquiret-Dumas V, Leman G, Chupin S, Baron S, Nivet-Antoine V, Vessieres E, Ayer A, Henrion D, Lenaers G, Reynier P, Procaccio V. 2015. Resveratrol Directly Binds to Mitochondrial Complex I and Increases Oxidative Stress in Brain Mitochondria of Aged Mice. PLoS One 10:e0144290. DOI:10.1371/journal.pone.0144290

Huang JG, Xia C, Zheng XP, Yi TT, Wang XY, Song G, Zhang B. 2011. 17beta-Estradiol promotes cell proliferation in rat osteoarthritis model chondrocytes via PI3K/Akt pathway. Cell Mol Biol Lett 16:564-575. DOI:10.2478/s11658-0110023-y

Jackson RL, Greiwe JS, Schwen RJ. 2011. Ageing skin: oestrogen receptor beta agonists offer an approach to change the outcome. Exp Dermatol 20:879-882. DOI:10.1111/j.1600-0625.2011.01362.x

Jiang H, Shang X, Wu H, Gautam SC, Al-Holou S, Li C, Kuo J, Zhang L, Chopp M. 2009. Resveratrol downregulates $\mathrm{PI} 3 \mathrm{~K} / \mathrm{Akt} / \mathrm{mTOR}$ signaling pathways in human U251 glioma cells. J Exp Ther Oncol 8:25-33.

Jover-Mengual T, Miyawaki T, Latuszek A, Alborch E, Zukin RS, Etgen AM. 2010. Acute estradiol protects CA1 neurons from ischemia-induced apoptotic cell death via the PI3K/Akt pathway. Brain Res 1321:1-12. DOI:10.1016/j.brainres.2010.01.046

Kaeberlein M, McDonagh T, Heltweg B, Hixon J, Westman EA, Caldwell SD, Napper A, Curtis R, DiStefano PS, Fields S, Bedalov A, Kennedy BK. 2005. Substrate-specific activation of sirtuins by resveratrol. J Biol Chem 280:17038-17045. DOI:10.1074/jbc.M500655200

Kang NH, Hwang KA, Lee HR, Choi DW, Choi KC. 2013. Resveratrol regulates the cell viability promoted by 17 beta-estradiol or bisphenol A via down-regulation of the cross-talk between estrogen receptor alpha and insulin growth factor-1 receptor in BG-1 ovarian cancer cells. Food Chem Toxicol 59:373-379. DOI:10.1016/j.fct.2013.06.029

Kitada M, Kume S, Imaizumi N, Koya D. 2011. Resveratrol improves oxidative stress and protects against diabetic nephropathy through normalization of Mn-SOD dysfunction in AMPK/SIRT1-independent pathway. Diabetes 60:634-643. DOI:10.2337/db10-0386

Kwon YJ. 2013. Resveratrol has anabolic effects on disc degeneration in a rabbit model. J Korean Med Sci 28:939-945. DOI:10.3346/jkms.2013.28.6.939

Ld S, Gutierrez S, Petiti JP, Palmeri CM, Mascanfroni ID, Soaje M, De Paul AL, Torres AI. 2012. 17beta-Estradiol modulates the prolactin secretion induced by TRH through membrane estrogen receptors via PI3K/Akt in female rat anterior pituitary cell culture. Am J Physiol Endocrinol Metab 302:E1189-1197. DOI:10.1152/ajpendo.00408.2011

Le MCL, Freemont AJ, Hoyland JA. 2007. Accelerated cellular senescence in degenerate intervertebral discs: a possible role in the pathogenesis of intervertebral disc degeneration. Arthritis Res Ther 9:R45. DOI:10.1186/ar2198

Li X, Phillips FM, An HS, Ellman M, Thonar EJ, Wu W, Park D, Im HJ. 2008. The action of resveratrol, a phytoestrogen found in grapes, on the intervertebral disc. Spine (Phila Pa 1976) 33:2586-2595. DOI:10.1097/BRS.0b013e3181883883

Lin CH, Lin CC, Ting WJ, Pai PY, Kuo CH, Ho TJ, Kuo WW, Chang CH, Huang CY, Lin WT. 2014. Resveratrol enhanced FOXO3 phosphorylation via synergetic activation of SIRT1 and PI3K/Akt signaling to improve the effects of exercise in elderly rat hearts. Age (Dordr) 36:9705. DOI:10.1007/s11357-014-9705-5

Liu MH, Yuan C, He J, Tan TP, Wu SJ, Fu HY, Liu J, Yu S, Chen YD, Le QF, Tian W, Hu HJ, Zhang Y, Lin XL. 2015. Resveratrol protects PC12 cells from high glucose-induced neurotoxicity via PI3K/Akt/FoxO3a pathway. Cell Mol Neurobiol 35:513-522. DOI:10.1007/s10571-014-0147-5

Macpherson L, Matthews J. 2010. Inhibition of aryl hydrocarbon receptor-dependent transcription by resveratrol or kaempferol is independent of estrogen receptor alpha expression in human breast cancer cells. Cancer Lett 299:119-129. DOI:10.1016/j.canlet.2010.08.010

Meng Z, Li J, Zhao H, Liu H, Zhang G, Wang L, Hu HE, Li DI, Liu M, Bi F, Wang X, Tian G, Liu Q, Buren B. 2015. 
Resveratrol relieves ischemia-induced oxidative stress in the hippocampus by activating SIRT1. Exp Ther Med 10:525530. DOI:10.3892/etm.2015.2555

Mo MS, Li HB, Wang BY, Wang SL, Zhu ZL, Yu XR. 2013. PI3K/Akt and NF-kappaB activation following intravitreal administration of 17beta-estradiol: neuroprotection of the rat retina from light-induced apoptosis. Neuroscience 228:1-12. DOI:10.1016/j.neuroscience.2012.10.002

Nwachukwu JC, Srinivasan S, Bruno NE, Parent AA, Hughes TS, Pollock JA, Gjyshi O, Cavett V, Nowak J, Garcia-Ordonez RD, Houtman R, Griffin PR, Kojetin DJ, Katzenellenbogen JA, Conkright MD, Nettles KW. 2014. Resveratrol modulates the inflammatory response via an estrogen receptor-signal integration network. Elife 3:e02057. DOI:10.7554/eLife.02057

Okoh VO, Felty Q, Parkash J, Poppiti R, Roy D. 2013. Reactive oxygen species via redox signaling to PI3K/AKT pathway contribute to the malignant growth of 4-hydroxy estradiol-transformed mammary epithelial cells. PLoS One 8:e54206. DOI:10.1371/journal.pone.0054206

Qi D, He J, Wang D, Deng W, Zhao Y, Ye Y, Feng L. 2014. 17ss-estradiol suppresses lipopolysaccharide-induced acute lung injury through PI3K/Akt/SGK1 mediated up-regulation of epithelial sodium channel (ENaC) in vivo and in vitro. Respir Res 15:1512. DOI:10.1186/s12931-014-0159-1

Robb EL, Stuart JA. 2011. Resveratrol interacts with estrogen receptor-beta to inhibit cell replicative growth and enhance stress resistance by upregulating mitochondrial superoxide dismutase. Free Radic Biol Med 50:821-831. DOI:10.1016/j.freeradbiomed.2010.12.038

Roy P, Kalra N, Prasad S, George J, Shukla Y. 2009. Chemopreventive potential of resveratrol in mouse skin tumors through regulation of mitochondrial and PI3K/AKT signaling pathways. Pharm Res 26:211-217. DOI:10.1007/s11095-008-9723-Z

Shen J, Hu Z, Zhong X, Wang D, Xu L. 2013. [Restoring phenotype of dedifferentiated normal nucleus pulposus cells by resveratrol]. Zhongguo Xiu Fu Chong Jian Wai Ke Za Zhi 27:547-553.

Sui XQ, Xu ZM, Xie MB, Pei DA. 2014. Resveratrol inhibits hydrogen peroxide-induced apoptosis in endothelial cells via the activation of PI3K/Akt by miR-126. J Atheroscler Thromb 21:108-118.

Tsai JH, Hsu LS, Lin CL, Hong HM, Pan MH, Way TD, Chen WJ. 2013. 3,5,4'-Trimethoxystilbene, a natural methoxylated analog of resveratrol, inhibits breast cancer cell invasiveness by downregulation of PI3K/Akt and Wnt/beta-catenin signaling cascades and reversal of epithelial-mesenchymal transition. Toxicol Appl Pharmacol 272:746-756. DOI:10.1016/j.taap.2013.07.019

Venkatachalam K, Mummidi S, Cortez DM, Prabhu SD, Valente AJ, Chandrasekar B. 2008. Resveratrol inhibits high glucoseinduced PI3K/Akt/ERK-dependent interleukin-17 expression in primary mouse cardiac fibroblasts. Am J Physiol Heart Circ Physiol 294:H2078-2087. DOI:10.1152/ajpheart.01363.2007

Wang H, Ding W, Yang D, Gu T, Yang S, Bai Z. 2014. Different concentrations of 17beta-estradiol modulates apoptosis induced by interleukin-1beta in rat annulus fibrosus cells. Mol Med Rep 10:2745-2751. DOI:10.3892/mmr.2014.2514

Wassmann S, Wassmann K, Nickenig G. 2004. Modulation of oxidant and antioxidant enzyme expression and function in vascular cells. Hypertension 44:381-386. DOI:10.1161/01.HYP.0000142232.29764.a7

Wuertz K, Quero L, Sekiguchi M, Klawitter M, Nerlich A, Konno S, Kikuchi S, Boos N. 2011. The red wine polyphenol resveratrol shows promising potential for the treatment of nucleus pulposus-mediated pain in vitro and in vivo. Spine (Phila Pa 1976) 36:E1373-1384. DOI:10.1097/BRS.0b013e318221e655

Yang SD, Bai ZL, Zhang F, Ma L, Yang DL, Ding WY. 2014. Levofloxacin increases the effect of serum deprivation on anoikis of rat nucleus pulposus cells via Bax/Bcl-2/caspase-3 pathway. Toxicol Mech Methods 24:688-696. DOI:10.3109/15376516.2014.963772

Yang SD, Ma L, Gu TX, Ding WY, Zhang F, Shen Y, Zhang YZ, Yang DL, Zhang D, Sun YP, Song YL. 2014. 17beta-Estradiol 
441 protects against apoptosis induced by levofloxacin in rat nucleus pulposus cells by upregulating integrin alpha2beta1. Apoptosis 19:789-800. DOI:10.1007/s10495-014-0965-4

Yang SD, Yang DL, Sun YP, Wang BL, Ma L, Feng SQ, Ding WY. 2015. 17beta-estradiol protects against apoptosis induced by interleukin-1beta in rat nucleus pulposus cells by down-regulating MMP-3 and MMP-13. Apoptosis 20:348-357. DOI:10.1007/s10495-015-1086-4

Zhao CQ, Liu D, Li H, Jiang LS, Dai LY. 2007. Interleukin-1beta enhances the effect of serum deprivation on rat annular cell apoptosis. Apoptosis 12:2155-2161. DOI:10.1007/s10495-007-0137-X

Zhou X, Chen M, Zeng X, Yang J, Deng H, Yi L, Mi MT. 2014. Resveratrol regulates mitochondrial reactive oxygen species homeostasis through Sirt3 signaling pathway in human vascular endothelial cells. Cell Death Dis 5:e1576. DOI:10.1038/cddis.2014.530

451

Zou Y, Zuo Q, Huang S, Yu X, Jiang Z, Zou S, Fan M, Sun L. 2014. Resveratrol Inhibits Trophoblast Apoptosis through 


\section{1}

Figure 1 FACS analysis for apoptotic incidence.

(A)NPCs were plated into 6-well plates at a density of $2 \times 10^{5}$ cells per well and divided into ten groups as presented in the figure. All groups were incubated for $24 \mathrm{~h}$ in the serum-free medium without phenol red. Apoptotic cells were detected using an Annexin V-FITC/PI kit (BD Pharmingen, San Jose, CA) according to the manufacturer's instructions. Apoptotic cells, stained positive for annexin V-FITC, negative for Pl, or double positive, were counted. (B)Data are represented as a percentage of the total cell count. Data analysis was determined by one-way analysis of variance (ANOVA) accompanied by pairwise comparison using SNK-q test. $* p<0.05$ by one-way analysis of variance (ANOVA) accompanied by pairwise

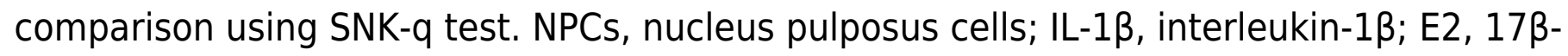
estradiol; RSV, resveratrol; mean \pm SD (standard deviation); $n=6$ 

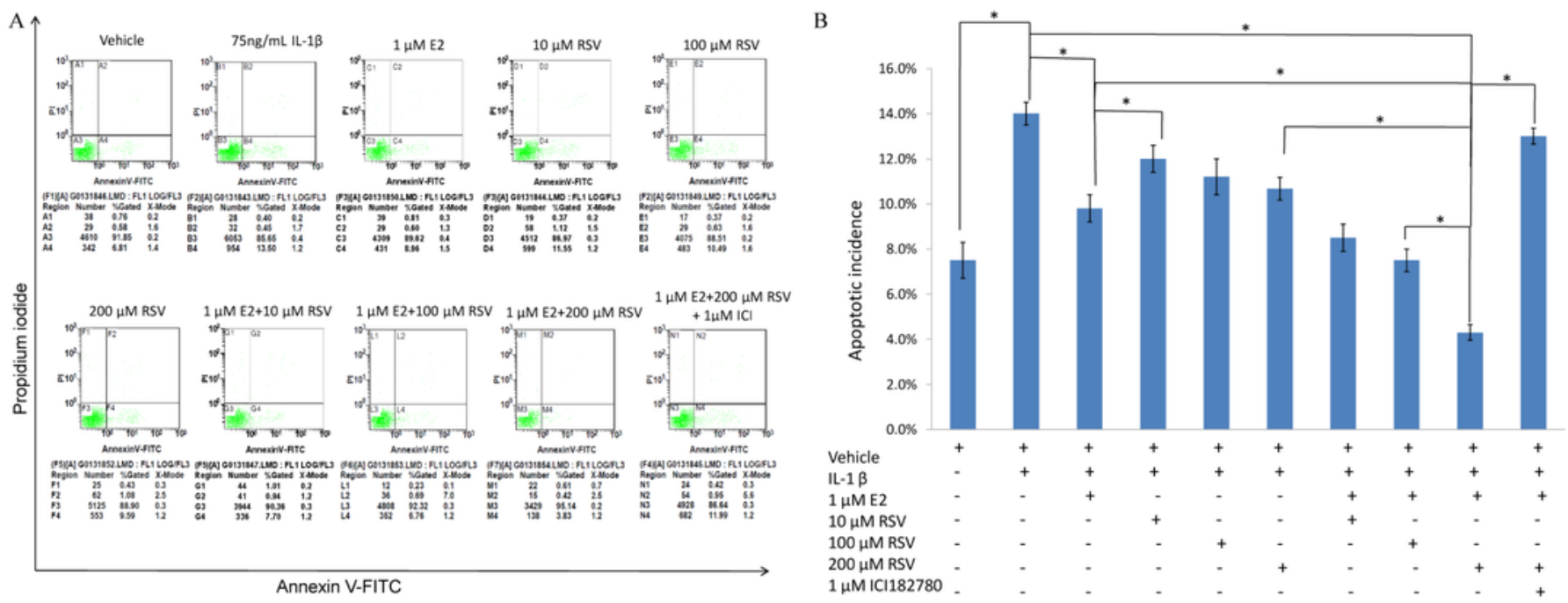


\section{2}

Figure 2 TUNEL assay for apoptosis

NPCs were divided into five groups. As a control, group A was treated with vehicle mixture (ethanol and DMSO, $<0.1 \%$; ethanol was the solvent of E2 and DMSO was the solvent of RSV). Group B was treated with $75 \mathrm{ng} / \mathrm{ml} \mathrm{IL-1 \beta}$. Group C was treated with $75 \mathrm{ng} / \mathrm{ml} \mathrm{IL-1 \beta}$ with the pretreatment of $1 \mu \mathrm{M}$ E2 for $30 \mathrm{~min}$. Group $D$ was treated with $75 \mathrm{ng} / \mathrm{ml} \mathrm{IL-1 \beta}$ with the pretreatment of $200 \mu \mathrm{M}$ RSV for $30 \mathrm{~min}$. Group E was treated with $75 \mathrm{ng} / \mathrm{ml} \mathrm{IL-1 \beta}$ with the pretreatment of $1 \mu \mathrm{M}$ E2 and $200 \mu \mathrm{M}$ RSV for $30 \mathrm{~min}$. All groups were incubated for $24 \mathrm{~h}$ in the serum-free medium without phenol red. All cells were stained red by PI, and apoptotic cells presented green. (A)Scale bar, $200 \mu \mathrm{m}$;(B)Scale bar, $50 \mu \mathrm{m}$; NPCs, nucleus pulposus cells; IL-1 $\beta$, interleukin-1 $\beta$; E2, 17 $\beta$-estradiol; RSV, resveratrol; PI, prodium iodide; $n=6$ 
A
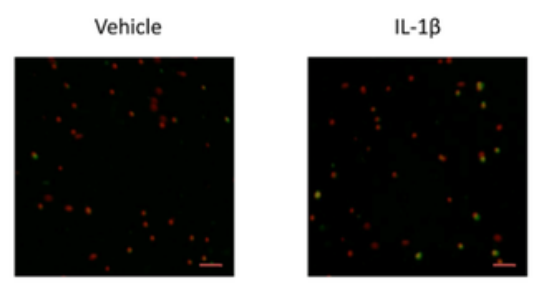

RSV

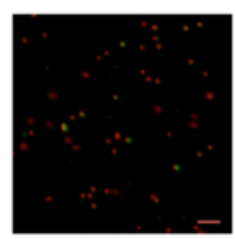

E2+RSV

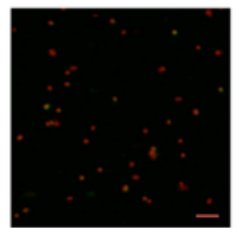

B

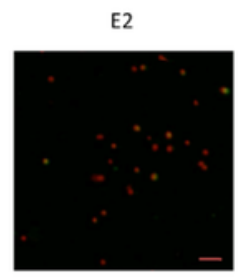

E2

RSV

E2+RSV
PI
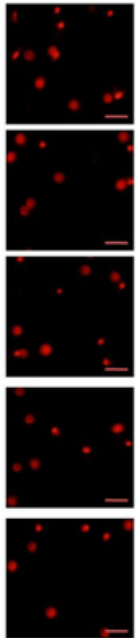
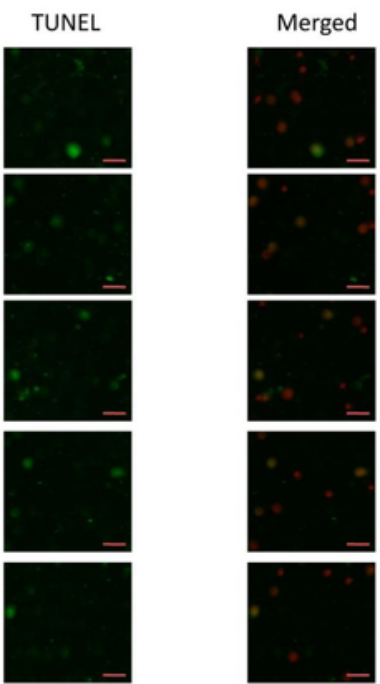


\section{3}

Figure 3 MTS assay for cell viability.

NPCs were treated in five groups as presented in the figure and then seeded into 96-well plates. All groups were incubated for $24 \mathrm{~h}$ in the serum-free medium without phenol red. Cell viability was determined by MTS assay using CellTiter $96{ }^{\circledR}$ AQueous MTS Reagent Solution (Promega, Madison, WI) according to manufacturer's instruction. The optical density was measured at $492 \mathrm{~nm}$ with a microplate reader (Shimadzu, Kyoto, Japan) and cell viability was normalized as a percentage of control. $* p<0.05$, by one-way analysis of variance (ANOVA) accompanied by pairwise comparison using SNK-q test. NPCs, nucleus pulposus cells; IL-1 $\beta$, interleukin-1 $\beta$; E2, 17 $\beta$-estradiol; RSV, resveratrol; mean \pm SD (standard deviation); $\mathrm{n}=6$

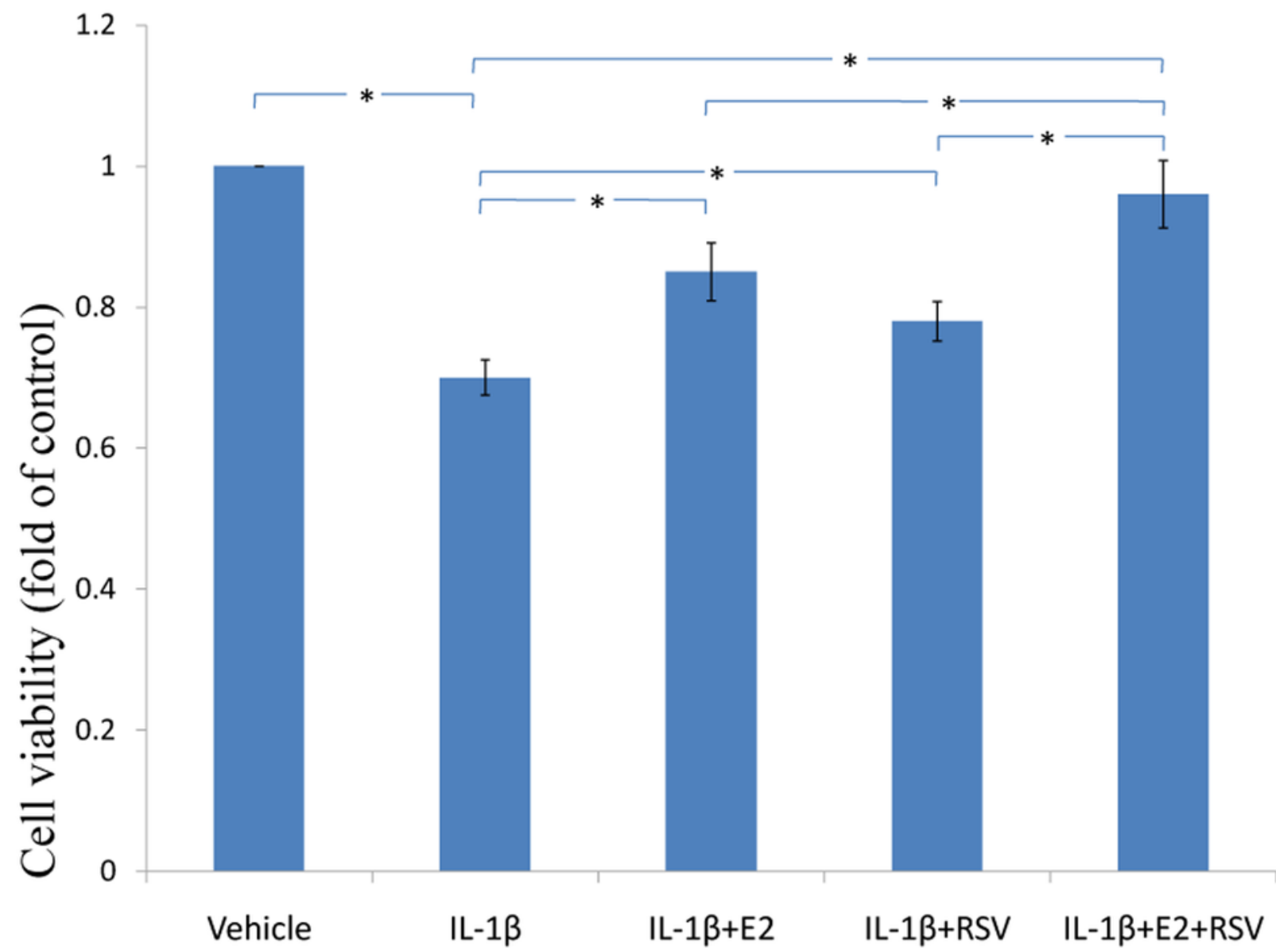




\section{4}

Figure 4 Cellular binding ability to type II collagen.

NPCs were divided into five groups. As a control, group A was treated with vehicle mixture (ethanol and DMSO, $<0.1 \%$; ethanol was the solvent of E2 and DMSO was the solvent of RSV). Group B was treated with $75 \mathrm{ng} / \mathrm{ml} \mathrm{IL-1 \beta}$. Group C was treated with $75 \mathrm{ng} / \mathrm{ml}$ IL-1 $1 \beta$ with the pretreatment of $1 \mu \mathrm{M}$ E2 for $30 \mathrm{~min}$. Group $D$ was treated with $75 \mathrm{ng} / \mathrm{ml} \mathrm{IL-1 \beta}$ with the pretreatment of $200 \mu \mathrm{M}$ RSV for $30 \mathrm{~min}$. Group E was treated with $75 \mathrm{ng} / \mathrm{ml} \mathrm{IL-1 \beta}$ with the pretreatment of $1 \mu \mathrm{M}$ E2 and $200 \mu \mathrm{M}$ RSV for $30 \mathrm{~min}$. All groups were incubated for $24 \mathrm{~h}$ in the serum-free medium without phenol red. ${ }^{*} p<0.05$, by one-way analysis of variance (ANOVA) accompanied by pairwise comparison using SNK-q test. NPCs, nucleus pulposus cells; IL-1 $\beta$, interleukin-1 $\beta$; E2, 17 $\beta$-estradiol; RSV, resveratrol; mean \pm SD (standard deviation); $\mathrm{n}=6$ 


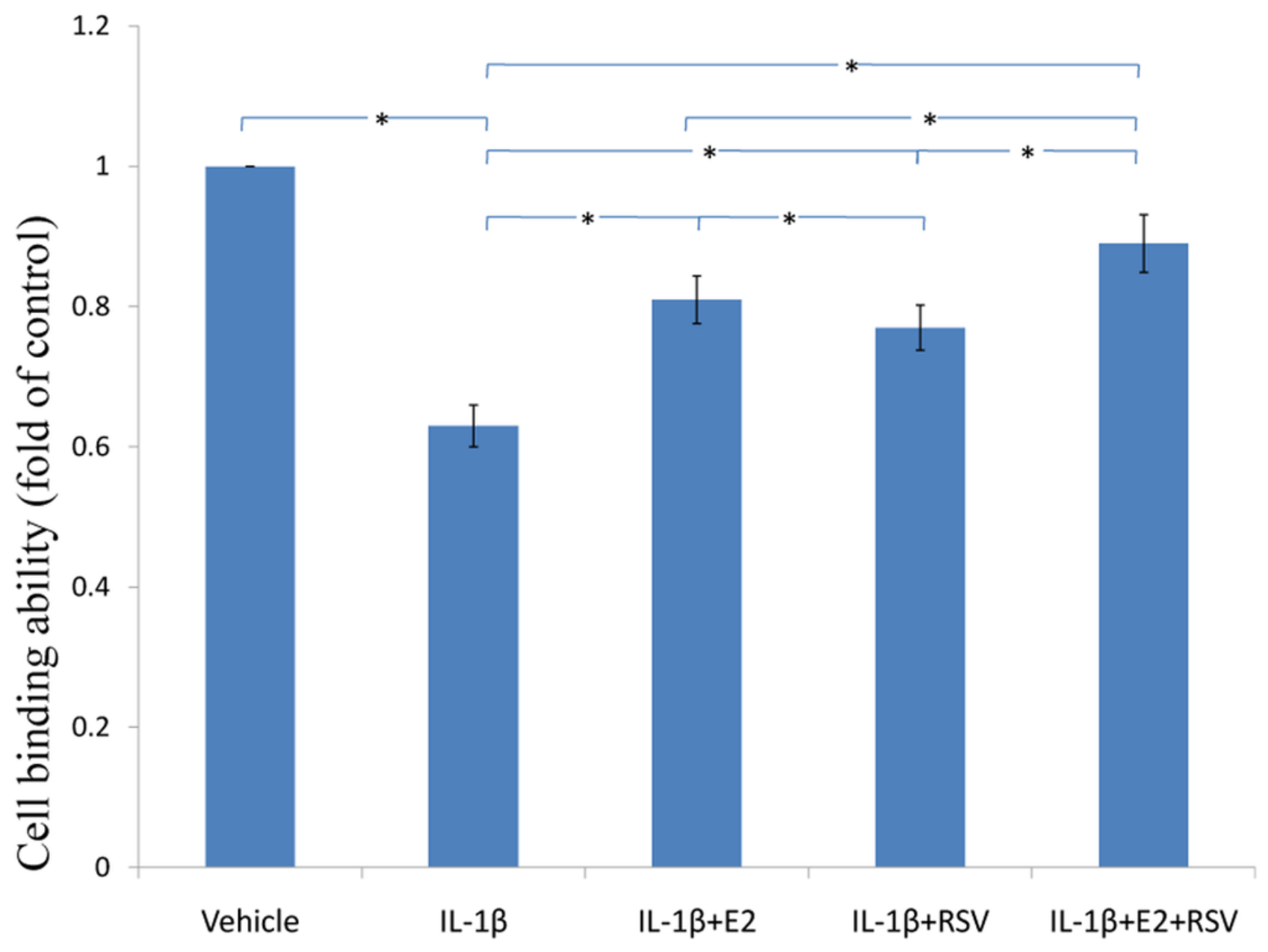




\section{5}

Figure 5 Active caspase-3 activity assay.

NPCs were divided into five groups. As a control, group A was treated with vehicle mixture (ethanol and DMSO, $<0.1 \%$; ethanol was the solvent of E2 and DMSO was the solvent of RSV). Group B was treated with $75 \mathrm{ng} / \mathrm{ml} \mathrm{IL-1 \beta}$. Group C was treated with $75 \mathrm{ng} / \mathrm{ml}$ IL-1 $1 \beta$ with the pretreatment of $1 \mu \mathrm{M}$ E2 for $30 \mathrm{~min}$. Group $D$ was treated with $75 \mathrm{ng} / \mathrm{ml} \mathrm{IL-1 \beta}$ with the pretreatment of $200 \mu \mathrm{M}$ RSV for $30 \mathrm{~min}$. Group E was treated with $75 \mathrm{ng} / \mathrm{ml} \mathrm{IL-1 \beta}$ with the pretreatment of $1 \mu \mathrm{M}$ E2 and $200 \mu \mathrm{M}$ RSV for $30 \mathrm{~min}$. All groups were incubated for $24 \mathrm{~h}$ in the serum-free medium without phenol red. Caspase-3 activity was determined using a caspase- 3 activity kit (Beyotime, Shanghai, China). Caspase- 3 activity is expressed as the fold change in enzyme activity over control. * $p<0.05$, by one-way analysis of variance (ANOVA) accompanied by pairwise comparison using SNK-q test. NPCs, nucleus pulposus cells; IL-1 $\beta$, interleukin-1 $\beta$; E2, 17 $\beta$-estradiol; RSV, resveratrol; mean \pm SD (standard deviation); $\mathrm{n}=6$ 


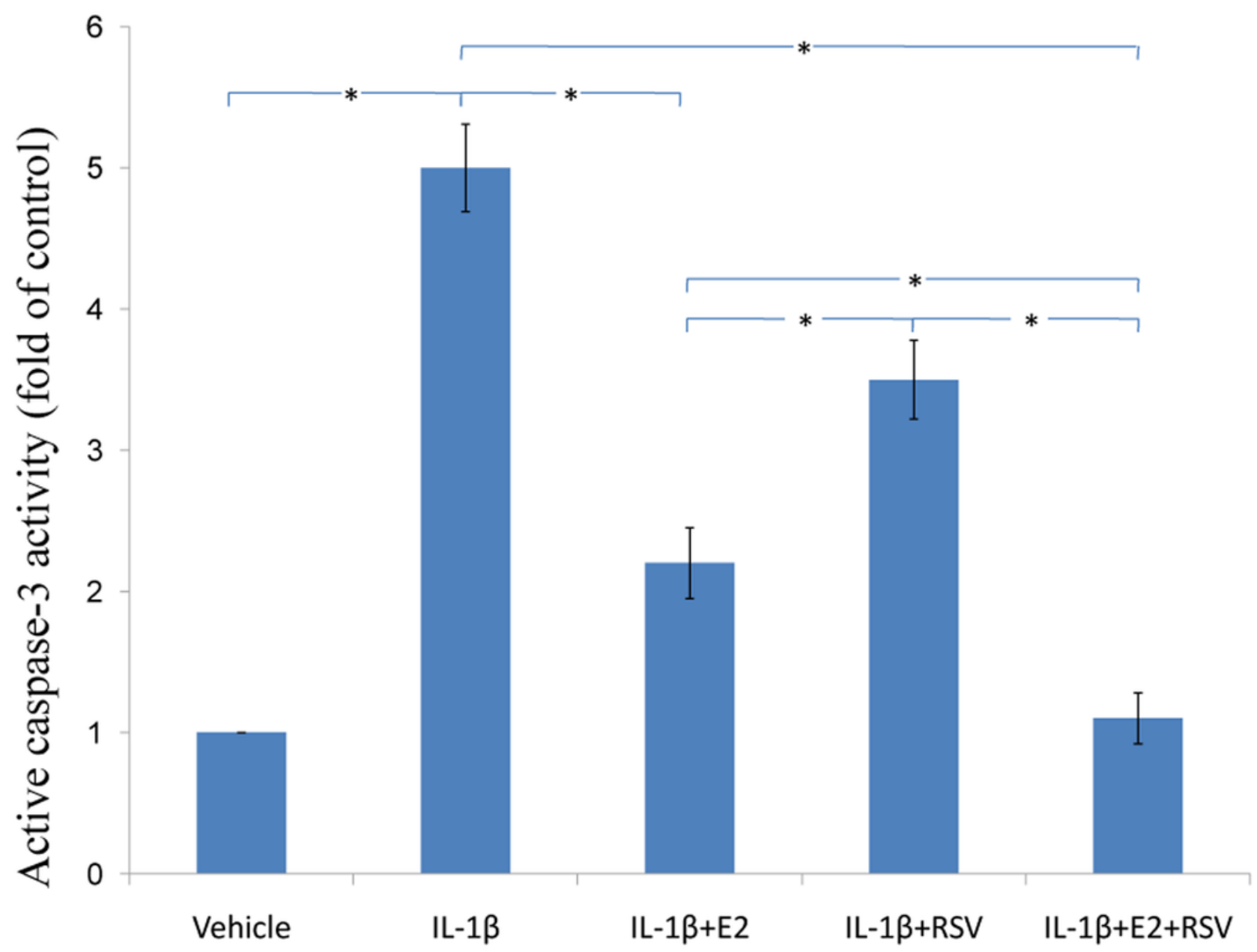




\section{6}

Figure 6 RT-qPCR analysis.

NPCs were divided into five groups. As a control, group A was treated with vehicle mixture (ethanol and DMSO, $<0.1 \%$; ethanol was the solvent of E2 and DMSO was the solvent of RSV). Group B was treated with $75 \mathrm{ng} / \mathrm{ml} \mathrm{IL-1 \beta}$. Group C was treated with $75 \mathrm{ng} / \mathrm{ml}$ IL-1 $1 \beta$ with the pretreatment of $1 \mu \mathrm{M}$ E2 for $30 \mathrm{~min}$. Group $D$ was treated with $75 \mathrm{ng} / \mathrm{ml} \mathrm{IL-1 \beta}$ with the pretreatment of $200 \mu \mathrm{M}$ RSV for $30 \mathrm{~min}$. Group E was treated with $75 \mathrm{ng} / \mathrm{ml} \mathrm{IL-1 \beta}$ with the pretreatment of $1 \mu \mathrm{M}$ E2 and $200 \mu \mathrm{M}$ RSV for $30 \mathrm{~min}$. All groups were incubated for $24 \mathrm{~h}$ in the serum-free medium without phenol red. ${ }^{*} p<0.05$, by one-way analysis of variance (ANOVA) accompanied by pairwise comparison using SNK-q test. NPCs, nucleus pulposus cells; IL-1 $\beta$, interleukin-1 $\beta$; E2, 17 $\beta$-estradiol; RSV, resveratrol; RT-qPCR, reverse transcription and real-time quantitative polymerase chain reaction; MMP, matrix metalloproteinase; mean $\pm S D$ (standard deviation); $n=6$ 

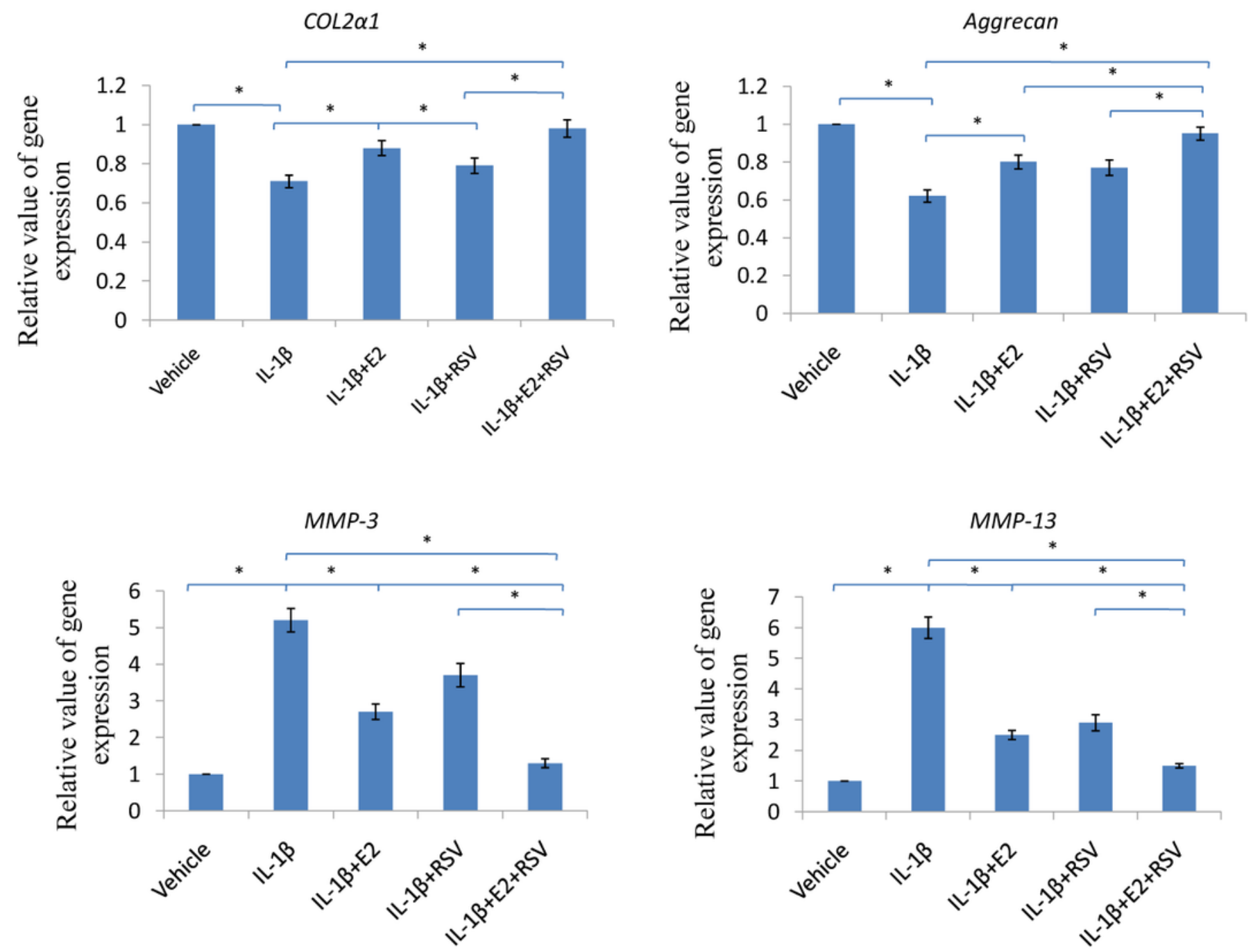


\section{7}

Figure 7 Protein levels of Akt, p-Akt(Ser473) and active caspase-3.

NPCs were divided into four groups. Group A was treated with $75 \mathrm{ng} / \mathrm{ml} \mathrm{IL-1 \beta .} \mathrm{Group} \mathrm{B} \mathrm{was}$ treated with $75 \mathrm{ng} / \mathrm{ml} \mathrm{IL-} 1 \beta$ with the pretreatment of $1 \mu \mathrm{M}$ E2 and $200 \mu \mathrm{M}$ RSV for $30 \mathrm{~min}$. Group C was treated with $75 \mathrm{ng} / \mathrm{ml} \mathrm{IL-1 \beta}$ with the pretreatment of $1 \mu \mathrm{M} \mathrm{E2,} 200 \mu \mathrm{M}$ RSV, and $1 \mu \mathrm{M} \mathrm{ICl}$ for $30 \mathrm{~min}$. Group D was treated with $75 \mathrm{ng} / \mathrm{ml}$ IL-1 $1 \beta$ with the pretreatment of $1 \mu \mathrm{M}$ E2, $200 \mu \mathrm{M}$ RSV and $50 \mu \mathrm{M}$ LY294002(PI3K/Akt inhibitor). All groups were incubated for $24 \mathrm{~h}$ in the serum-free medium without phenol red. $* p<0.05$, by one-way analysis of variance (ANOVA) accompanied by pairwise comparison using SNK-q test. NPCs, nucleus pulposus cells; IL-1 $\beta$, interleukin-1 $\beta$; E2, 17ß-estradiol; ICI, ICl182780; RSV, resveratrol; LY, LY294002, $50 \mu \mathrm{M} ;$ mean $\pm \mathrm{SD}$ (standard deviation); $\mathrm{n}=6$ 

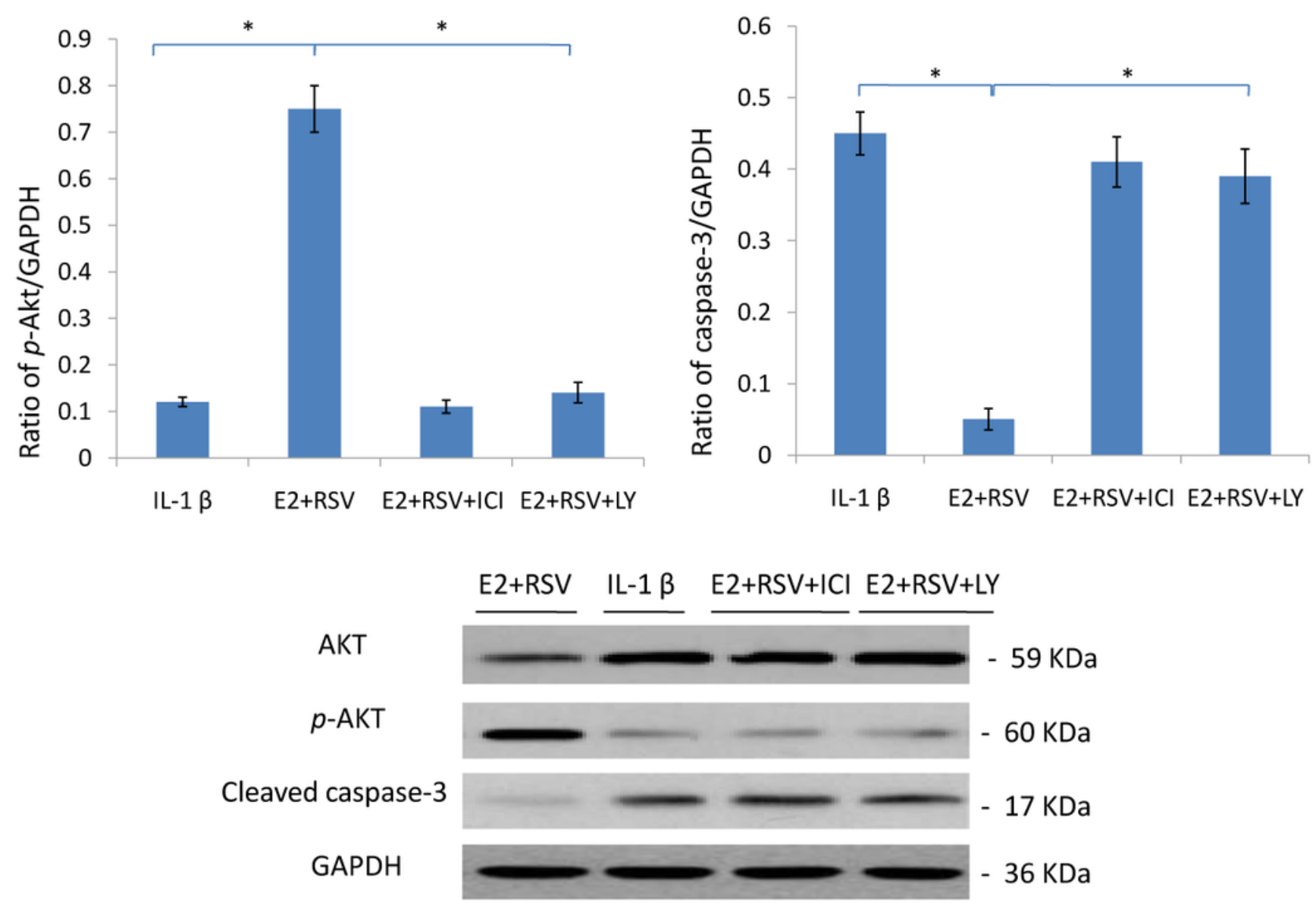


\section{Table 1 (on next page)}

Table 1

Reagents and antibodies used in the experiments 
1 Table 1 Reagents and antibodies used in the experiments.

\begin{tabular}{lllcc}
\hline Reagents/antibodies & Manufacturers & City/Country & Catalog No. & Source \\
\hline FBS & Gibco & New York, US & $10099-141$ & Bovine \\
caspase-3 p17 antibody & Santa Cruz & Santa Cruz, CA & sc-98785 & Rabbit \\
Akt antibody & Cell Signaling & Beverly, MA & 2920 & Mouse \\
p-Akt antibody & Cell Signaling & Beverly, MA & 12694 & Mouse \\
GAPDH & Proteintech & Wuhan, China & $10494-1-$ AP & Rabbit \\
IL-1 $\beta$ & Peprotech & Rocky Hill, NJ & $400-01 B$ & Rat \\
secondary antibodies & Proteintech & Wuhan, China & SA00001 & Goat \\
resveratrol & Sigma-Aldrich & St. Louis, MO & R5010 & grape skin \\
trypsin & Sigma-Aldrich & St. Louis, MO & T4049 & Porcine \\
collagenase type II & Sigma-Aldrich & St. Louis, MO & C2139 & Rat \\
17ß-estradiol & Sigma-Aldrich & St. Louis, MO & 491187 & N/A \\
DMSO & Solarbio & Beijing, China & D8372-100 & N/A \\
DMEM/F12 & Gibco & New York, US & $11320-033$ & N/A \\
TUNEL detection kit & Promega & Madison, WI & G3250 & N/A \\
MTS Reagent Solution & Promega & Madison, WI & G3582 & N/A \\
caspase-3 activity kit & Beyotime & Shanghai, China & C1115 & N/A \\
LY294002 & Selleck Chemicals & Huston, TX & S1105 & N/A \\
ICI182,780 & Selleck Chemicals & Huston, TX & S1191 & N/A \\
PE Annexin V Apoptosis & BD Pharmingen & San Jose, CA & 559763 & N/A \\
Detection Kit I & & & & \\
2 & & & & \\
\hline & & & &
\end{tabular}




\section{Table 2 (on next page)}

Table 2

Primers used in the study 
1 Table 2 Primers used in the study

\begin{tabular}{|c|c|c|c|}
\hline No. & Target gene & $\begin{array}{c}\text { Sequence } \\
\text { (sense, anti-sense, 5'-3') }\end{array}$ & $\begin{array}{l}\text { Accession No. } \\
\text { (GenBank) }\end{array}$ \\
\hline 1 & $\operatorname{COL} 2 \alpha 1$ & $\begin{array}{l}\text { ACGCTCAAGTCGCTGAACAA } \\
\text { TCAATCCAGTAGTCTCCGCTCT }\end{array}$ & NM_012929 \\
\hline 2 & Aggrecan & $\begin{array}{l}\text { TCCAAACCAACCCGACAAT } \\
\text { TCTCATAGCGATCTTTCTTCTGC }\end{array}$ & NM_022190 \\
\hline 3 & MMP-3 & $\begin{array}{l}\text { ATGATGAACGATGGACAGATGA } \\
\text { CATTGGCTGAGTGAAAGAGACC }\end{array}$ & NM_133523 \\
\hline 4 & MMP-13 & $\begin{array}{l}\text { GGCCAGAACTTCCCAACCA } \\
\text { ACCCTCCATAATGTCATACCC }\end{array}$ & NM_133530 \\
\hline 5 & GAPDH & $\begin{array}{l}\text { GGAAAGCTGTGGCGTGAT } \\
\text { AAGGTGGAAGAATGGGAGTT }\end{array}$ & NM_017008 \\
\hline
\end{tabular}

